\title{
VYUŽITÍ SYSTÉMOVÉ DYNAMIKY V OBLASTI ŽIVOTNÍHO PROSTŘEDÍ: NA PŘ́KLADU ODPADOVÉHO HOSPODÁŘSTVÍ MĚSTA ZNOJMA
}

THE UTILIZATION OF SYSTEM DYNAMICS IN THE
ENVIRONMENT: THE EXAMPLE OF WASTE MANAGEMENT FROM
THE CITY OF ZNOJMO

\section{ING. ET ING. STANISLAV ČURDA, PH.D. ${ }^{1}$}

ING. Michal PLAČEK, M.Sc. ${ }^{1}$

\author{
ING. MILAN PŮČEK, MBA, PH.D. ${ }^{2}$ \\ ${ }^{1}$ Katedra ekonomie a veřejné správy $\mid{ }^{1}$ Department of Economics and Public Administration \\ Soukromá vysoká škola ekonomická Znojmo Private College of Economic Studies in Znojmo \\ $\bowtie$ Loucká 42, 66902 Znojmo, Czech Republic \\ E-mail: placek@svse.cz \\ ${ }^{2}$ Centrum pro sociální a ekonomické strategie ${ }^{2}$ Centre for Social and Economic Strategies \\ Fakulta sociálnich věd Faculty of Social Sciences \\ Univerzita Karlova v Praze Charles University in Prague \\ $\triangle$ Celetná 20, 11636 Praha, Czech Republic \\ E-mail:milan.pucek@seznam.cz
}

\begin{abstract}
Anotace
Cílem článku je využit nástroje systémové dynamiky pro rozvoj a řizeni města, a to na konkrétním připadu odpadového hospodářstvi Města Znojma (na problému nakládání s biodpady - odhad produkce bioodpadu). Druhým cilem je popsat vazby odpadového hospodárství na rozpočet města a provést benchmarking s městy se stejnou velikosti a strukturou odpadového hospodářství. K naplněni cilů byla provedena analýza dostupných zdrojů, byla vedena diskuze s odborniky $k$ identifikaci hlavních faktorů ovlivňujici produkci biodpadu. Byly použity tyto metody: analýza literatury a dostupných zdrojů, srovnávaci analýzy (benchmarking), strukturované rozhovory sodborniky, objektivizace analýz, systémově dynamické modelováni procesů. Výsledkem práce je kromě analyzovaných dat a provedených srovnání zejména diagram kauzálních vazeb, jež může sloužit jako základ pro vytvořeni dynamického modelu a v také v neposledni řadě odpovědným činitelưm města pro uvědomèni si základnich vazeb a kauzalit v extrémně komplexním systému jakým je odpadového hospodářství.
\end{abstract}

\section{Klíčová slova}

odpadové hospodářství, systémová dynamika, benchmarking, rozpočet

\section{Annotation}

This article deals with the utilization of system dynamics for the development and management of cities, with emphasis on the particular case of waste management in Znojmo (regarding the issue of mangement of Biodegradable waste - estimation of Biodegradable waste). The second objective is to describe the links between waste management and municipal budgets and to apply benchmarking to cities of similar size and with a similar structure of waste management. To meet the objectives, an analysis of available resources was provided and discussions were held with experts in order to identify the main factors influencing the production biodegrable waste. The following methods were used: an analysis of the literature and of the available resources, comparative analysis (benchmarking), structured interviews with experts, corroboration of the analysis, and system dynamic 
modeling processes. The result of this work is an addition to the analyzed data and applied benchmarking, in particular the causal links diagram, that serve as a tool for city officials to be used for the realization of the fundamental links and causality within extremely complex systems such as waste management.

\section{Keywords}

waste management, system dynamic, benchmarking, budget

JEL classification: $R 1, R 5, C 1$

\section{1. Úvod}

Obce v ČR mají ze zákona povinnost zajistit rozvoj svého území. Využití systémové dynamiky může obcím při zabezpečování rozvoje pomoci lépe pochopit situaci a potřebné vazby. Jako zakladatele systémové dynamiky můžeme označit J. Forresterea profesora na Massachusets Institute of Technology (Forrester, 1989). Aplikaci systémové dynamiky v managementu se zabýval Peter Senge v knize pátá disciplýna (Senge, 1994), zavádí kategorii systémového myšlení, kde se neklade důraz na matematické modelování, ale na pochopení celistvosti systému a vazeb mezi jednotlivými prvky a kauzalitami tohoto systému. Velmi komplexní popis podstaty aplikace této metody různé modely poskytuje Sterman, blíže viz. (Sterman, 2000) Pokud se zaměříme na aplikaci v oblasti municipalit, byla systémová dynamika poprvé aplikována v rámci implementace systému Balanced Scorecard ve městě Vsetín (Hušek, Šusta, Půček, 2006), na rozdíl od klasické BSC tak jak ji známe od autorů Kaplana a Nortona (Kaplan, Norton, 2001), se jednalo rozšíření modelu na tzv. 3. generaci BSC. Bylo vytvořeno několik modelů, např́íklad model populace města Vsetín, model pracovního trhu, bohužel tyto modely nebyly naplněny reálnými daty a použity pro reálnou aplikaci (Půček, Koppitz, Otrusilová, 2013). Pro účely teorie byly naplněny reálnými daty a testovány na to, jak jsou schopny vystihnout realitu až v roce 2013 (Půček, Koppitz, Otrusilová, 2013)). Hlavní př́nos dynamických modelů lze shrnout do následujících bodů: (1) systemizace myšlenkových pochodů, (2) usnadnění komunikace mezi lidmi, (3) výchova a výcvik, (4) predikce chování modelovaného systému, (5) experimenty, (6) pochopení reálného systému, (7) parametrické studie reálného systému, (8) náhrada za experimenty s reálným systémem (Burianová, 2007).

Výzkum se věnuje možnostem využití nástrojů systémové dynamiky v oblasti životního prostředí konkrétně v oblasti nakládání s odpady. Náklady na hospodaření s odpady jsou velmi významnou položkou rozpočtu každého města. Průměrný náklad na občana za zpracování odpadů byl v ČR v roce 2011 912Kč. Podrobnější srovnání přináší následující tabulka:

Tab. 1: Srovnání vybraných nákladi̊ na obyvatele s průměrnými náklady obcí velikosti 20001 50000 obyvatel v rámci kraje a ČR za rok 2011

\begin{tabular}{|c|c|c|c|}
\hline \multirow{2}{*}{ Činnost } & \multicolumn{3}{|c|}{ Náklady v Kč/obyvatel/rok } \\
\cline { 2 - 4 } & Znojmo & JM kraj & ČR \\
\hline Náklady směsného KO & 739,40 & 557 & 515 \\
\hline Svoz tř́ídéných odpadů & 143,60 & 106 & 145 \\
\hline Náklady na sběrný dvůr & 203,70 & 104 & 98 \\
\hline Svoz odpad. košù & 88,90 & - & 38 \\
\hline Náklady celkem & $\mathbf{1 1 8 7 , 5 0}$ & $\mathbf{9 1 6}$ & $\mathbf{9 1 2}$ \\
\hline \multicolumn{3}{|c|}{ Zdroj: EKO-KOM a.s.Analýza odpadového hospodářství Města Znojma } \\
\hline
\end{tabular}

Z tabulky vyplývají př́činy vyšších nákladů na občana ve Městě Znojmě v porovnání $\mathrm{s}$ Jihomoravským kraje a celorepublikovým průměrem $\mathrm{v}$ daných kategoriích. Velmi vysokých hodnot dosahují položky, jako jsou náklady na sběrný dvůr a náklady směsného KO. 
Tato situace se samozřejmě promítá do celkových nákladů systému odpadového hospodářství, které mají vrůstající trend (2009 - 38mil., 2010 - 36 mil., 2011 - 40mil.).,

Stejně zajímavým ukazatelem je výše dotace systému ze strany obce v porovnání s ČR. Do roku 2012 mohly obce stanovit podíl občanů na úhradě činnosti odpadového systému formou místního poplatku do výše 500Kč. Znojmo má tento poplatek na maximální úrovni, takže dominantním problémem je nákladnost celého systému. Tento závěr nám potvrzuje i tabulka porovnání nákladů na občana. Od roku 2013 mají obce možnost zvýšit místní poplatek až na 1000 Kč.

Tab. 2: Podíl dotace systému odpadového hospodářství na nákladech Znojmo vs ČR

\begin{tabular}{|l|l|l|l|}
\hline & 2009 & 2010 & 2011 \\
\hline Znojmo & $51,53 \%$ & $47,81 \%$ & $53,3 \%$ \\
\hline ČR & $29 \%$ & $28 \%$ & $32 \%$ \\
\hline
\end{tabular}

Zdroj: EKO-KOM a.s.,Analýza odpadového hospodárství Města Znojma

Pokud budeme zvažovat nákladovost systému a možné budoucí faktory, které mohou hrát roli při zvyšování nákladů, musíme bezpochyby zmínit zavádění sběru biologicky rozložitelného odpadu a možné navýšení poplatku za skládkování. Navýšení poplatku za skládkování je záležitost daná legislativou v horizontu let. Pokud se však zaměřme na problém biodpadu, je město nuceno učinit v poměrně krátké době rozhodnutí, jakým způsobem bude problém řešit a zvažovat možné dopady na celkové náklady systému.

\section{Cíl a metody}

Předmětem zkoumání této studie je analýza odpadového hospodářství Města Znojma s využitím nástrojů systémové dynamiky. Výzkumné cíle jsou následující: (1) Využít nástroje systémové dynamiky pro rozvoj a řízení města, a to na konkrétním př́ípadu odpadového hospodářství Města Znojma. (2) Druhým cílem je popsat vazby odpadového hospodářství na rozpočet města a provést benchmarking s městy se stejnou velikostí a strukturou odpadového hospodářství. Při naplňování výzkumných cílů byl použit mix normativní a nenormativní metodologie a jemu odpovídající výzkumné metody. Pozitivní metodologie byla použita zvláště při analýze a deskripci problému, při studiu zdrojů a analýze dat. Základní kriteriální otázkou při tomto druhu analýzy je: „Co se stalo? Jaký je stav zkoumaného problému?“. Následně jsme se pokusili formulovat „nejlepší“ (optimální) řešení s ohledem na zvolená kritéria a omezující podmínky. Stavíme si normativní otázku: „Jaký výsledný cílový stav by byl vhodný (žádoucí) pro město?“. Empirickou bází pro danou analýzu bylo období roků 2009 až 2011, a to zejména z důvodu získání potřebných dat. Empirická analýza se opírá jak o sekundární tak i o primární data. $V$ rámci výzkumu byly použity tyto metody: analýza literatury a dostupných zdrojů, srovnávací analýzy (benchmarking), strukturované rozhovory s odborníky, objektivizace analýz, systémově dynamické modelování procesů.

\section{Výsledky}

\subsection{Odpadové hospodářství}

V rámci výzkumu identifikovali autoři následující problémy, o kterých bude muset Město Znojmo v oblasti odpadového hospodářství rozhodnout: (1) Poplatek pro občany za biologicky rozložitelný odpad. (2) Jakým způsobem bude motivovat občany, aby odpad tř́́dili a ukládali žádoucím způsobem. (3) Jakým způsobem bude Město službu pro občany zajišt’ovat. (4) Určení optimálního počtu nádob. (5) Určení předpokládaného množství biologického odpadu

Jak bylo uvedeno, znalost produkce bioodpadů na území obce, jejich jednotlivé druhy a hmotnostní toky jsou zásadní pro vytvoření strategie nakládání s bioodpady, které jsou významnou součástí odpadového hospodářství obce. Vliv primárních dat na nastavení optimálního systému jak pro provoz, tak pro ekonomickou stránku věci je velmi významný. 
Produkce bioodpadů $\mathrm{v}$ př́ípadě, kdy obec začíná vytvářet prvotní systém nakládání s nimi a nemá žádná historická data, se stávajícími metodami stanovuje velmi nedokonale a validita odhadů produkce v budoucnu je rovněž velmi nízká. Může se proto stát, že dojde k navržení a vytvoření systému, který následně nebude plnit očekávání a jeho provoz se bude muset následně měnit. Do jisté míry je to dáno i tím, že odhad produkce bioodpadů probíhá velmi povrchně a není proveden více metodami tak, aby došlo k vzájemné kontrole a následně k úpravě hodnot. Velmi často se jako zdroj bioodpadu berou pouze zdroje, které lze co možná nejsnadněji kvantifikovat, ale to neznamená, že představují majoritní část produkce. Zákonitě následují odchylky v množství produkce a tím i v hmotnostních a druhových tocích, což má vliv na ekonomiku koncového zařízení. Často dojde k odhadu veličiny bez zasazení do širších souvislostí.

Při tvorbě analýzy produkce bioodpadů pro město Znojmo - „Analýza potenciálu produkce odpadů Biologicky rozložitelný odpad“ -byl použit nejčastěji využívaný model stanovením procentuální složky bioodpadů ve směsném komunálním odpadu. Velmi často je tato procentuální hodnota přejímána $\mathrm{z}$ různých studií a proto nemusí odrážet stav v navrhovaném území. $\mathrm{V}$ tomto konkrétním př́padě studie rovněž převzala cizí hodnoty. Na př́slušné části studie je zřejmé, jak jsou tyto odhady produkce prováděny. Tento stav bude demonstrován na pasáži:

„4. Aktuální a budoucí produkce odpadů - Biologicky rozložitelný odpad z domácností“

Výňatek č.1 z analýzy:,,Dle údajů ČSÚ (Zpráva „Produkce, využití a odstranění odpadu v roce $2010^{\prime)}$ činilo množství směsného komunálního odpadu připadajicí na jednoho obyvatele $\check{C} R 317 \mathrm{~kg}, \mathrm{z}$ toho největši část $71 \%$ tvořil běžný svoz, 16 \% tříděný odpad (sklo, papir, plasty) a $11 \%$ objemný odpad. Celkové množství BRKO uloženého na skládky v roce 2010 činilo 1, 377 mil. tun, což je v prepočtu na obyvatele $131 \mathrm{~kg}$, tedy o $19 \mathrm{~kg}$ více než byl cílový stav (za rok 2010 měl být snižen podíl uloženého BRO na skládky na 75 \% hmotnostnich ve srovnáni s rokem 1995, což mělo být $112 \mathrm{~kg}$ ). Místo požadovaných $75 \%$ tak bylo uloženo $90 \%$ množství roku 1995. Podíl BRKO v SKO činí aktuálně přibližně 40 - $60 \%$ hmotnosti. Produkce SKO v poslednich pěti letech mirně vzrůstá (približně o $2-3 \%$ hmotnostni ročně), což je dáno zejména vzrůstajici životni úrovní obyvatelstva. Přitom v některých letech dochází $k$ udrženi stavu z předchozího roku, což je dáno zejména zavádèním a rozšiřováním separovaného sběru některých odpadů (zejména obalů). " (Pánská, 2012)

Komentář k výňatku č. 1:Je zřejmé, že jde o obecné sdělení, které se zájmovým územím nesouvisí, protože v rámci produkce směsného komunálního odpadu došlo v letech 2009 - 2011 k poklesu o 565 tun (což je o cca 8,5\%). Pokud jsou data produkce směsného komunálního odpadu brána jako podklad pro odhad budoucí produkce, pak má studie opačný trend než je realita.

Výňatek č. 2 z analýzy:,,Množství obyvatel je podle nejnovější středni prognózy ČSÚ na nejbližši léta možno považovat za přibližně konstantní. Složeni SKO procházi v poslednich letech vývojem, který je možno charakterizovat postupným zvyšováním podilu biologicky rozložitelných složek ze $40 \%$ v roce 1995 až na $48 \%$ v roce 2000, $54 \%$ v roce 2010, $56 \%$ v roce 2013 s předpokladem růstu až na $60 \%$ v roce 2020. Zde zmíněné prognózy předpokládaji, že nebudou zavádèny postupy, které by mohly výrazně snižit množství SKO a v něm obsažených biologicky rozložitelných složek. Jedná se o zavedeni separovaného sběru BRKO vyplývajici z novely zákona o odpadech. $Z$ výše uvedeného vyplývá, že jako reálný podíl BRKO v SKO lze na úrovni celé ČR $v$ současnosti a blízké budoucnosti brát v úvahu úroveň kolem 40 - 50 \% hmotnostnich. “(Pánská, 2012)

Komentář $\mathbf{k}$ výňatku č. $2: Z$ této části je evidentní, že pro výpočet dojde pouze $\mathrm{k}$ upravení dat dle prognózy ČSUU, která průměruje stav v celé ČR např́ič různými typy aglomerací. Bohužel právě tento způsob odhadu produkce bioodpadů je nejčastější. Není možno řešit, které jednotlivé druhy bioodpadů jsou započítány do uvedených 40 - $50 \%$ hmotnostních a tak ani nevíme, zda je s nimi možno v tomto konkrétním př́padě počítat. Tento nedostatek je zřejmý v kontextu další užívané metody, která je popsána níže a kde čistě „bioodpad“ představuje jen do cca 20 \% ze směsného komunálního odpadu.

Další využívaný způsob pro odhad množství produkce bioologicky rozložitelného odpadu vychází z analýzy skladby komunálního odpadu. Zde již nalezneme podrobnější rozbor, kdy druhotné suroviny jsou vedeny samostatně a nenavyšují tak produkci. Rovněž se projevuje snaha postihnout různé typy aglomerací a tím i jejich specifika v množství produkce. 
Jako základ pro výpočet (odhad) je počet obyvatel a hodnota roční produkce jednoho obyvatele. Pokud ale dochází pouze $\mathrm{k}$ převzetí této hodnoty, může dojít rovněž k chybě - jde totiž o průměrné hodnoty a pokud není proveden samostatný rozbor skladby komunálního odpadu, tak je třeba alespoň provést korekci na místní produkci komunálního odpadu.

Tab. č. 3: Zastoupení biodpadu v produkci směsného komunálního odpadu (kg/obyv./rok)

\begin{tabular}{|l|l|l|l|l|}
\hline & \multicolumn{3}{|l|}{ Podíl látkových skupin v odpadu (kg/obyv./rok), průměrné hodnoty } \\
\hline & $\begin{array}{l}\text { Sídlištní zástavba } \\
\text { velkých měst }\end{array}$ & $\begin{array}{l}\text { Sídlištní zástavba } \\
\text { menších měst }\end{array}$ & $\begin{array}{l}\text { Smísená } \\
\text { zástavba měst }\end{array}$ & $\begin{array}{l}\text { Venkovská } \\
\text { zástavba }\end{array}$ \\
\hline Bioodpad & $\mathbf{2 8}$ & $\mathbf{2 5}$ & $\mathbf{2 7}$ & $\mathbf{1 2}$ \\
\hline Celkem & 156 & 130 & 156 & 198 \\
\hline
\end{tabular}

$\mathrm{V}$ př́ípadě města Znojma tedy docházíme díky popsaným metodám $\mathrm{k}$ dvěma různým závěrům:

Tab. 4: Varianta 1

\begin{tabular}{|l|l|l|}
\hline Rok & $\begin{array}{l}\text { Směsný komunální } \\
\text { odpad }\end{array}$ & Biologicky rozložitelný odpad \\
\hline 2009 & $7235,858 t$ & $2894 t(40 \%$ SKO) až $3618 t(50 \%$ SKO) \\
\hline 2010 & $6921,006 t$ & $2768 t(40 \%$ SKO) až 3 461 t (50\% SKO) \\
\hline 2011 & $6670,852 t$ & $2668 t(40 \%$ SKO) až 3 335 t (50\% SKO) \\
\hline
\end{tabular}

Tab. 5: Varianta 2

\begin{tabular}{|l|l|l|}
\hline Produkce(kg/obyv./rok) & Počet obyvatel & Biologicky rozložitelný odpad \\
\hline 27 & 34476 & $931 t$ \\
\hline
\end{tabular}

Hodnoty pro rok 2010 a celkový počet obyvatel - předchozí odhad totiž také využil jako výchozí celkovou produkci směsného komunálního odpadu.

Porovnání odhadu pro rok 2010 vypovídá, že druhý způsob udává hodnotu 33,6 \% nebo 26,9 \% ze způsobu prvního. Rozhodně tedy nelze mluvit o drobné statistické chybě.

Jak je patrné výsledky jsou diametrálně odlišné a je těžké se na jejich základě rozhodovat o tom, jak bude systém svozu a dalšího nakládání s bioodpady dimenzován. Pokud by byl systém budován zcela nově a výchozí hodnot a produkce by byla určena druhým způsobem, došlo by nejspíše k výraznému poddimenzování kapacit. Pokud by na jejich vybudování byla využita dotace, další náklady by již neslo samo město.

Jako př́iklad finančního dopadu rozhodnutí na základě nesprávných dat lze uvést případ, kdyby město Znojmo zrrizovalo zařízení pro nakládání s bioodpady na základě předpokladu úspor. Rozdíl mezi cenou, kterou město Znojmo platí za ukládání směsného komunálního odpadu na skládce a odstraněním bioodpadu na kompostárně je $710 \mathrm{Kč/t}$. Podle prvního modelu by očekávaná úspora při zř́zení kompostárny představovala 1965 tis. Kč za rok (popř. 2457 tis. Kč/rok) dle dat z roku 2010. Pokud by byl pravdivý druhý způsob odhadu produkce, pak by úspora tvořila jen 661 tis. Kč/rok což je cca $1 / 3$ popř. $1 / 4$ proti odhadu první metodou. Město Znojmo by tedy mělo vybudované předimenzované zařízení, u kterého by byl problém naplnit jeho kapacitu a i návratnost investice by byla výrazně jiná než by byla prvotní očekávání.

U hodnocené analýzy produkce byl dán malý prostor tomu, že zadavatel uvažuje o zavedení systému jen pro určitou specifickou část bioodpadů. Jedná se o produkci bioodpadů z údržby soukromé zeleně. Je to dáno tím, že zadavatel disponuje zařízením, kde není v této době možno odstraňovat bioodpady ze směsného komunálního odpadu a $\mathrm{v}$ tomto smyslu se zvolená metodika odhadu jako podílu směsného komunálního odpadu jeví jako naprosto nevyhovující. Navíc plánovaný systém se týká pouze části města a tím by bylo nutné provádět další korekce výpočtu. $K$ využití nepř́liš vhodného 
modelu došlo asi tím, že postup stanovení zdrojů bioodpadu a následná kvantifikace je poměrně náročná a to již v prrípadě stanovení aktuální produkce.

Pro stanovení přesnějších hodnot by bylo vhodné vytvořit systém pro stanovení produkce, který bude odpovídat místním podmínkám (např́klad zohlední různé druhy zástavby) a bude reflektovat i na další požadavky zadavatele. Specifické požadavky se mohou týkat jak zaměření se na produkci určitých druhů odpadů z důvodu již existujícího zařízení pro odstraňování odpadů nebo prognózu v delším časovém výhledu.

Pro vytvoření takovéhoto systému je třeba zmapovat jednotlivé zdroje a toky odpadů. Pro vytvoření odhadu v čase je pak nutné stanovit veličiny, které produkci ovlivňují a mohou se v čase měnit. U těchto hodnot pak najít trend vývoje a s touto veličinou následně kalkulovat. Systém by měl být vytvořen tak, aby se jednoduchým způsobem daly namodelovat různé varianty. To by umožnilo posoudit kvalitu jednotlivých systémů a př́padně jejich ekonomickou náročnost. Pro vytvoření takovéhoto modelu se jeví jako vhodná metoda využívající systémové dynamiky.

\subsection{Využití systémové dynamiky}

Při tvorbě modelu postupujeme následujícím způsobem:

- Definování problému - zde je nutné jasně definovat, co vlastně chceme modelovat a jaké cíle tím chceme dosáhnout. Modelování znamená určité zjednodušení reality, proto je nutné stanovit určité hranice modelu a rozhodnout o tom, které proměnné budeme modelovat.

- Definování systémových prvků modelu - je nutné definovat všechny jednotlivé části modelu, určit jednotky $\mathrm{v}$ jakých je zachytíme, úlohu $\mathrm{v}$ modelu např. konstanta, zásobárna, tok, parametr

- Mentální vyjádření modelu - velmi účinné je grafické znázornění modelů pomocí diagramu toků, nebo smyčkových diagramů, hlavním cílem této fáze je uvědomění si kauzalit a vlastností jednotlivých prvků modelu. Grafické vyjádření je běžná součást software zabývajícího se systémovou dynamikou a existují přesné konvence zápisu modelu.

- Formalizace modelu - zde se pokoušíme určit závislost jednotlivých proměnných a definovat rovnice modelu, snažíme se tedy popsat, jak se mění hodnoty stavových veličin $\mathrm{X} v$ čase $\mathrm{t}$ $(\mathrm{X}(\mathrm{t})$ na hodnotu $v$ čase $\mathrm{t}+\Delta \mathrm{t}$, tedy na $\mathrm{X}(\mathrm{t}+\Delta \mathrm{t})$, kde $\mathrm{t}+\Delta \mathrm{t}$ znamená nepatrně malou změnu $\mathrm{v}$ čase). Změny hodnoty stavových veličin můžeme popsat následovně:Diskrétními modely čas rozdělíme na rovnoměrné intervaly délky $\mathrm{dt}$ a výpočty provádíme pouze $\mathrm{v}$ těchto diskrétních intervalech, $v$ bodech $\mathrm{t}_{\mathrm{n}}=\mathrm{t}+\mathrm{n}^{*} \Delta \mathrm{t}$ počítáme hodnoty $\mathrm{y}_{\mathrm{n}}$ zbytek aproximujeme. Alternativou jsou spojité modely- čas nelze rozdělit na diskrétní kroky, používáme diferenciální rovnice $\mathrm{dx} / \mathrm{dt}$ - změna hodnoty proměnné v čase t. Samozřejmě lze také použít kombinace předchozích přistupů. Pro řešení diferenčních rovnic $\mathrm{v}$ modelech můžeme použít Eulerovu metodu $\mathrm{y}_{\mathrm{n}+1}=\mathrm{y}_{\mathrm{n}}+\Delta \mathrm{t} * \mathrm{f}\left(\mathrm{y}_{\mathrm{n}}, \mathrm{t}\right)$, tato metoda skýtá omezení zejména při použití $\mathrm{u}$ modelů s vysokofrekvenčními oscilacemi. Další variantou je použití Runge - Kutta integrační metody (2. a 4. Řádu), což je sofistikovanější metoda aproximace, jež vyžaduje více operací, ale poskytuje přesnější výsledky. Tato metoda není vhodná pro modely s čistě diskrétními prvky, na čistě spojitých dosahuje lepších výsledků než Eulerova metoda.(Pelánek, 2011). Podrobnější matematickou intuici pro modelování napřr. v oblasti biologie lze nalézt např́íklad v (Ellner, Guckenheimer, 2006).

- Tvorba simulačního období - zde musíme určit délku období pro simulaci, časový krok, tj. jak často bude model provádět matematické výpočty a metodu integrace (Eulerova vs Runge Kutta) 


\section{Obr. 1: Systémově dynamický model nakládání s bioodpady ve Městě Znojmě}

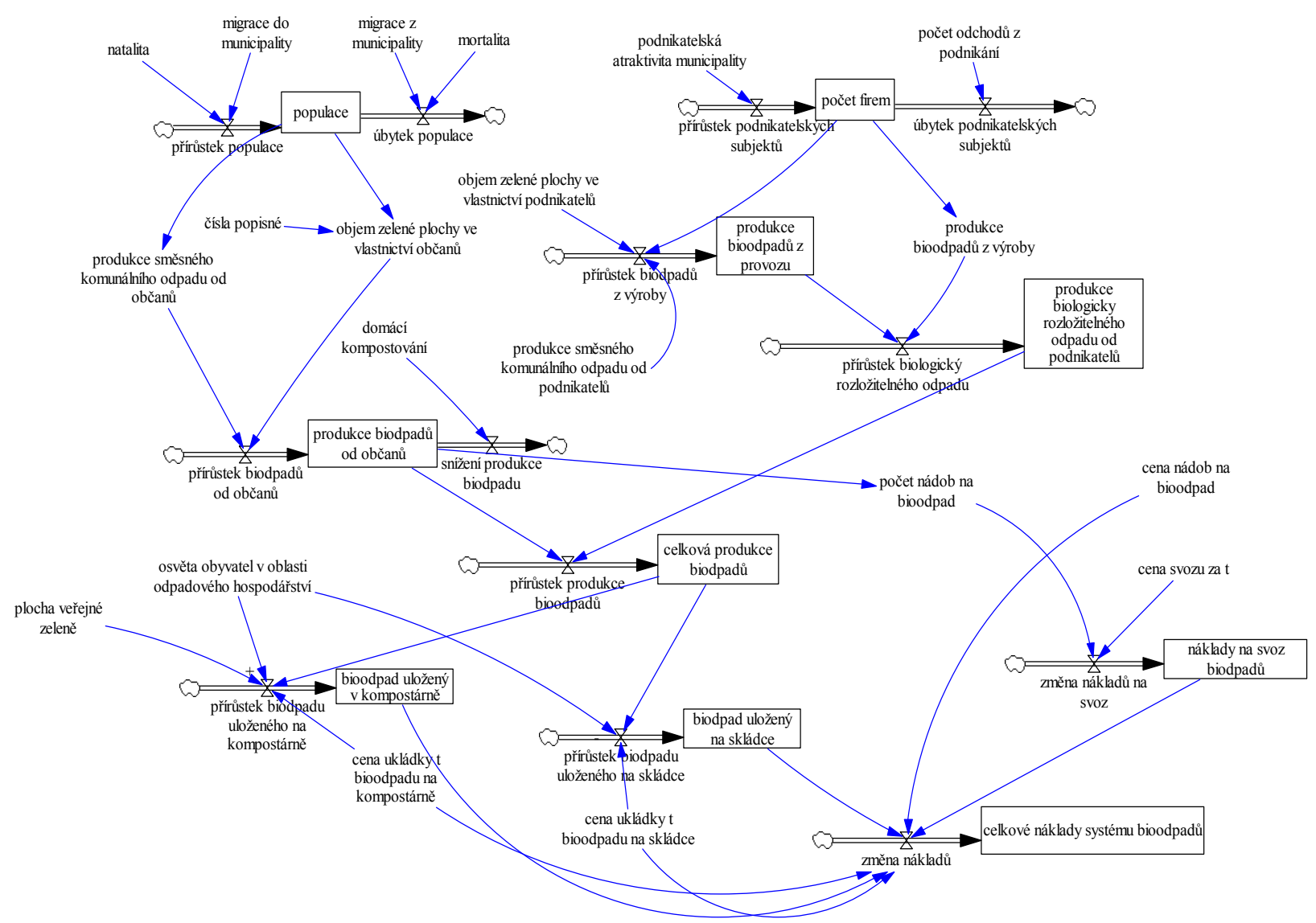

Zdroj: autoři

\section{Závěr}

Odpadové hospodářství je velmi komplexní systém. Důležitost kvalitního řízení tohoto systému $\mathrm{v}$ budoucnosti poroste, nebot' $\mathrm{s}$ velkou pravděpodobností porostou také náklady na obsluhu tohoto systému a systém se bude měnit dynamičtěji než doposud. Což můžeme demonstrovat právě na řešení problému s bioodpady. Systémová dynamika nám tedy může pomoci efektivněji řídit systém odpadového hospodárství a vyrovnat se s náhlými změnami. Simulace různých variant vývoje systému umožňuje lépe vyhodnotit dopady rozhodnutí odpovědných zástupců města na systém a také na jeho náklady. Samozřejmě je nutné zmínit omezení, které nám použití systémové dynamiky přináší. Každý model znamená určitou míru zjednodušení reálného světa a není ani žádoucí, aby systém byl popsán do nejmenších detailů, nebot' bychom se vystavili riziku, že pro př́lišnou detailnost ztratíme přehled o nejvýznamnějších faktorech, jež ovlivňují systém. Výstupy z modelu nám spíše udávají základní intervaly hodnot, v nichž se při různých variantách vývoje můžeme pohybovat, než konkrétní čísla. Jedním z největších kladů systémové dynamiky je však efekt učení se. I přesto, že se nám ne vždy může povést připravit využitelný model, můžeme si alespoň pomocí smyčkového diagramu, který použiváme pro grafickou část modelu, uvědomit komplexnost systému a ty nejdůležitější kauzality, které systém ovlivňují. 


\section{Literatura}

[1] BURIANOVÁ, E. Simulace dynamických modeli̊ s využitím metod systémové dynamiky. ISKI, 2007 Využití operačných systémov a počitačových sietí v podpoře výučby informatických predmetov.

[2] Český statistický úřad. Produkce, využití a odstranění odpadů v roce 2011, Český statistický úřad, Odbor statistiky zemědělství, lesnictví a životního prostředí, Praha, 2011.

[3] EKO-KOM. Analýza odpadového hospodářství Města Znojma. EKO- KOM, Praha 2012

[4] ELLNER, S. P, GUCKENHEIMER J. Dynamic models in Biology. Princeton: Princeton University Press, 2006. 326 p. ISBN 978-0-691-12589-3.

[5] FORRESTER W.J. The Beginnings of Systems Dynamics. The McKinsey Quarterly 1995, Number 4

[6] Hlášeni o produkci a nakládání sodpady 2009, 2010 a 2011 ve městě Znojmo.

[7] HUŠEK, Z., ŠUSTA, M., PŮČEK, M. Aplikace metody Balanced Scorecard (BSC) ve veřejném sektoru. Praha: Národní informační středisko pro podporu jakosti, 2006. 144 s. ISBN 80-0201861-3.

[8] KAPLAN S. R., NORTON P. D. Balanced Scorecard: Translating Strategy into Action. Harvard Business SchoolPress, 1996. ISBN 0-87584-651-3.

[9] KOTOULOVÁ, Z., VÁŇA, J. Intenzifikace sběru, dopravy a tříděni komunálních odpadů, výzkumný projekt VaV/720/2/00, Praha: Univerzita Karlova v Praze, Př́rodovědecká fakulta, Ústav pro životní prostředí, 2003, Dílčí projekt 1 - Stanovení skladby komunálních odpadů, Praha, SLEEKO, 2003.

[10] PÁNSKÁ,L. Znojmo - Analýza potenciálu produkce odpadi̊ - Biologicky rozložitelný odpad 2012. Brno: GEOtest, srpen 2012.

[11] PELÁNEK, R. Modelování a simulace komplexnich systémů. Brno: Masarykova univerzita, 2011. ISBN 978-80-210-5318-2.

[12] PŮČEK, M., KOPPITZ D., OTRUSILOVÁ M. Practical use of the Dynamic Balanced Scorecard in the City. Proceedings o fthe 17th. International Conference.Current Trends in Public Sector Research.1.st. Brno:Masarykova universita, 2013. 320s. ISBN 978-80-210-6159-0.

[13] SENGE, P. The Fifth Discipline: The Art and Practise of the Learning Organization, Doubleday. New York, 1990. ISBN 978-0-385-26095-4.

[14] STERMAN, J. D. Business Dynamics: Systém Thinking and Modeling for a Complex World. McGraw-Hill 2000, p. 982. ISBN 0-07-231135-5. 